\title{
Instead of a Review; or, What, and Thanks to Whom, Do We Know About a Man at War?
}

\author{
Irina Trotsuk \\ Associate Professor, Peoples' Friendship University of Russia \\ Address: Miklukho-Maklaya str. 10/2, 117198 Moscow, Russian Federation \\ E-mail: irina.trotsuk@yandex.ru
}

\begin{abstract}
This article was initially intended to be a review of War, a book by Arkady Babchenko published in 2015, but turned out to be more of an essay. On one hand, the purpose in publishing a book in 2015 about the two Chechen military campaigns may be questioned especially since Babchenko had previously published numerous texts about his recent experiences as a war journalist. On the other hand, War is full of sociological issues, which eliminates any doubt about the possibility of writing a review of this definitely non-sociological book for a sociological journal. In fact, such books revive a new round of debates on two topics important for the sociological discourse. The first considers the status of the "stories" of ordinary witnesses of the events, and their logic of narration has obtained the same legitimate status as scientific narratives; that is why sociologists are interested in the everyday "testimonies" within the "micro-" approach to the study of war. The question that underlines the second topic of the debates is central for contemporary society in general, that is, who has the right to write about war and to suggest linguistic, thematic, discursive, and implicit ideological formats to speak and to think about it? Certainly, there are adequate, institutionalized methodological models to study and to write about war. However, the macro-optical perspective inevitably misses the substantial meanings and emotions that turn wars into the most epiphanic moments of our lives expressed in biographical narratives. To overcome this limitation, we turn to the narratives of those who happened to witness wars from "within", either to fictional narratives (represented by The Kindly Ones, authored by Jonathan Littell), or to non-fictional stories (represented by Pathologies, written by Zakhar Prilepin). The latter are more typical for contemporary Russian tradition and, thus, are considered on the example of War. However, both fiction and non-fiction narratives allow us see the "human dimension of war"; they differ, perhaps, only in the power of conviction, and the level of trust.
\end{abstract}

Keywords: war, Arkady Babchenko, narrative analysis, fiction and non-fiction, Jonathan Littell, Zakhar Prilepin, "micro-" and "macro-" approaches to the sociological study of war

\section{Is There Any Sense in Reviewing Non-scientific Books on War?}

Thanks to the media that constantly informs us very quickly, distantly, unemotionally, and in between commercials while sometimes providing expert opinions (often far less comprehensible for an average person than the news) of tragic war events all around the world, we all claim to be competent enough in the causes and consequences of all the

(C) Irina Trotsuk, 2015

(C) Russian Sociological Review, 2015

DOI: $10.17323 / 1728-192 \mathrm{X}-2015-4-173-190$ 
war conflicts we are aware of. For instance, if asked, anyone could mention that the scale and number of wars have recently increased, that their key features have radically transformed, and that we all live in an epoch of violent confrontations between tribal, ethnic, and religious factions battling with both primitive and the most sophisticated weapons without state-supported armies and resources, and that previous distinctions between civilians and soldiers are challenged. Some people completely deny the acceptability of warfare as a method of resolving contradictions. Others accept the use of war as an extreme form of armed violence to achieve certain goals because they either refuse to consider the moral aspects of war and exaggerate its ability to achieve the desired goal, or recognize the temporary permissibility of this evil for the sake of moral values (the so-called "just war"). Both would agree that no official or scientific definitions and explanations help us understand the very essence of war that has not changed for centuries, because man's feelings in the thick of the battle are shown only in fiction and non-fiction books, at least in terms of the authors' intentions. This is why these types of books are becoming more and more numerous and popular, regardless of the horrific events described (let us be honest and confess that there are enough sad moments in our everyday life and no obvious reason to multiply our sorrows by reading about wars), and the remarkably long history of scientific attempts to explain, model, and prevent wars.

The text below was initially intended to be a review of War, a book by Arkady Babchenko and published in Moscow in 2015, but to write a review on such a book today seems to be a task either too simple (leaving out all the accompanying contexts and focusing on the narrative as it is or its sociological meaning) or, on the contrary, too complicated (not leaving anything out). That is why I must warn our readers that this essay does not claim to be a classical review in the full sense of the word, although the idea of such a review seemed both appealing and questionable to me from the very beginning due to the personality of the author. Arkady Babchenko calls himself a "war child" since he fought in the first Chechen war at the age of 19, and also took part in the second Chechen campaign. His experiences became the basis of his highly-acclaimed autobiographical novel One Soldier's War in Chechnya (precisely and convincingly capturing the fear, chaos, and brutality of contemporary combat, and published in English in 2007) that won Russia's Debut Prize, which recognizes authors who write "despite, and not because of, their life circumstances." This experience made Babchenko a journalist, a founder of a veterans' association, and the Internet site "Art of War." In Chechnya, he fought in major cities and tiny mountain villages, and describes both Chechen wars in a number of devastating first-person narratives. In these texts, we see the raw and mundane realities of war presented by an extraordinary storyteller for whom such narratives are a means of coping with harrowing memories': "Writing was the only thing that helped ... If I had not started writing, I might have lost myself to drink. It was the only real cure. When a person comes back from war, from prison, from any extreme situation, he has to get it out from himself. The whole horrific experience-he needs to vent it ..."

\footnotetext{
1. http://www.theguardian.com/books/2007/nov/21/biography
} 
There is no need to provide additional links to the interviews Babchenko gave to both the Russian and Western media to summarize what he consistently says about the war in Chechnya. In his recently-published book War, he wrote that Russian authorities branded the war as a restoration of "the constitutional order," while the Chechens (although it is a too-general label to use when talking about the entire population of the republic) believed it was a war for national liberation. However, his purpose in publishing his book in 2015 about the two Chechen campaigns may be questioned, especially since Babchenko published enough texts about his recent experience as a Novaya Gazeta war journalist in the Ukraine, and in Georgia in 2008, writing extensively about the absolute hatred that has appeared in these two regions ${ }^{2}$. The answer becomes obvious by doing two things: (1) by reading some interviews and Facebook posts by Babchenko in which he partly explains the need to return once more to the most tragic pages of Russian contemporary history that are still difficult to explain and understand, and; (2) by reading War, since it does make one truly believe that this is one of the most timely books among war prose ever written.

According to his numerous publications in various (mainly Internet) editions, Babchenko is sure that what happened in Chechnya during two war campaigns explains how Russian soldiers are treated, and what war is, especially the urban warfare within the borders of a single country. Babchenko believes that the story of Chechnya is an open textbook written in blood which no one wants to read or learn from. It is important to note that while many of his critics consider Babchenko to have Post-Traumatic Stress Disorder which he writes about or even to be a schizophrenic whose mind was forever broken by the war, no one doubts that he is an honest journalist and one of the founders of contemporary Russian war prose. He is able to speak of war without pathos or embellishment, presenting a autobiographically-based story about everyday life in the Chechen war-endless days, full, though not with heroism, but with hatred, pain, and fear, and, at the same time, with hope, and a crazy, devouring thirst for life, to survive and to remain human after and outside the war which forever alters the fates of all people involved. Babchenko emphasizes the fictional character of his book as not being autobiographical, but rather as a reflection of the events that happened to him (he notes that $80 \%$ to $90 \%$ of the events described did happen), and claims that the book was not meant as a book or a literature, but rather as attempt at rehabilitation in not having one's past in a backpack, because "the best way to get rid of war is to tell about it" (Babchenko, 2015: 7).

However, even after I started a kind of a review you are reading, I continued to question the possibility of writing such a doubtfully-sociological text on a definitely nonsociological book for a sociological journal. As most social scientists would agree, the realities often dispel doubts. In my case, these were the debates that followed with the Belarusian author and journalist Svetlana Alexievich winning the 2015 Nobel Prize in Literature. Actually, the discussions of this inspiring event (no matter how you personally perceive it) in the history of post-Soviet literature in Russian can be divided into two

2. See, e.g., http://www.threekingsblog.com/tag/arkadiy-babchenko 
groups. The first type of debates focus on the political background of the Swedish Academy's decision in the current international situation, i.e., on recognizing and supporting Alexievich as a longtime critic of the Soviet regime, and more recently, of the Russian government, and Belarusian President Alexander Lukashenko. This is a consistent pattern in the perception of the Swedish Academy's decisions in seeking political motives, (especially in Russia), but the least interesting for this essay.

The second line of debates includes the criticisms of the 2015 Nobel Prize in Literature decision for the "status" of Svetlana Alexievich's books. According to Sara Danius, the Permanent Secretary of the Swedish Academy, Alexievich won the award because she "has offered us new historical material and a new genre." ${ }^{3}$ Those who accepted the decision of the Swedish Academy and congratulated the post-Soviet literature in Russian for it consider the works of Alexievich non-fiction and, thus, worthy of the award ${ }^{4}$. People who disagree with the decision of the Swedish Academy consider the works of Alexievich as pure journalism and not worthy of the Nobel Prize in Literature, intended primarily and solely for fiction. The grounds for this line of argument are obvious. Alexievich's books weave the voices of hundreds of interview subjects ${ }^{5}$ together in exploring the most tragic pages of Russia's recent history, including the 1986 Chernobyl disaster, the Soviet Union's war in Afghanistan, ${ }^{6}$ and the experience of Soviet women who were on the front lines during World War II. ${ }^{7}$ These are the parts of the expansive project Voices of Utopia, which the Swedish Academy evaluated worthy of the Nobel Prize in Literature for "polyphonic writings, a monument to suffering and courage in our time"s. Alexievich has consistently chronicled what has been intentionally forgotten, from the Soviet war in Afghanistan to Chernobyl to the post-Soviet 199os (the subject of her most recent book).

The 2015 Nobel Prize in Literature, in fact, unexpectedly launched (or, better to say, revived) a new round of debates on two topics important for the sociological discourse. The first thematic line is within-disciplinary (although interdisciplinary, in essence) and considers the status of narratives in contemporary science. No one would challenge the thesis that the "narrative turn" emphasized the textual nature of all social practices or negatively estimate the methodological and technical consequences of its legitimization in explaining all social events through discourses that constitute social reality and iden-

3. http://www.nobelprize.org/nobel_prizes/literature

4. Although in recent decades the world's most prestigious literature prize has been awarded to writers of non-fiction very seldom, for example, to Bertrand Russell and Winston Churchill in 1950 and 1953 respectively.

5. By the way, Haruki Murakami, named among the Nobel nominees, once wrote a kind of the same type of non-fiction book Underground: The Tokyo Gas Attack and the Japanese Psyche (it was published in Russian in 2008, almost ten years after its first Japanese edition, and much later than the English version released in 2003) about the 1995 Aum Shinrikyo sarin gas attack on the Tokyo subway. The book is made up of a series of interviews with those who were affected by the attacks of the members of the religious cult Aum. Using a similar format, Murakami wanted to capture the way the attack had affected average citizens, and those who suffered the more serious after-effects, either the members and ex-members of the doomsday cult or the victims of the attack.

6. These two books are available in English-Voices from Chernobyl: The Oral History of a Nuclear Disaster and Zinky Boys: Soviet Voices from the Afghanistan War.

7. War's Unwomanly Face was published in 1985, and was hugely popular in the Soviet Union.

8. http://www.nobelprize.org/nobel_prizes/literature 
tification models in contemporary society. However, there is one ambiguous result of the "narrative turn," that being the shaken status and credibility of the sociological (and broader-scientific) discourse. This is because the notion "narrative" is generally accepted as a legitimate characteristic of both the respondent's and the sociologist's texts other than description or logical and statistical explanations, due to its temporal structure, historical design, and rhetorical mode of explanation. Therefore, no less than everyday actors, sociologists (and all scientists, for we are not the only "victims" here) are "narrators," telling "stories" to explain how they transform narratives of everyday actors and empirical objects into some spatial, temporal, and logical configurations generally accepted as valid and reliable scientific explanations.

In other words, the narratives of ordinary witnesses of the events and their logic of narration (and even larger due to the "naturalness" and immediacy of the life experience) obtained the same legitimate status as scientific narratives; that is why sociologists study these everyday "testimonies" (Franzosi, 1998: 517). The so-called "narrative research/ sociology" proceeds from the following assumptions: all individuals are socialized storytellers, and are constantly in the situation of potential narration; most of the speech acts contain elements of narrative; the content and structure of narrative depends on the situation, audience, individual perspectives, and the power hierarchy; narratives can confront each other or interact; all narratives are incomplete by nature due to different levels of the narrators' linguistic competence, uncertainty of the narrators' position, differences in the length and degree of institutionalization, and an endless interpretation process, all of which results in the same narrator presenting different versions/narratives of the same events to different audiences at different times (see, e.g., Maines, 1993).

\section{What Kind of "Optics" Does the Scientific Approach Provide?}

There are two conventional approaches to the sociological study of war; let us call them the "macro-" and the "micro-" approaches. The latter is represented by narrative analysis, but not in the traditional philosophical-historical interpretation developed, for instance, by F. Ankersmit, who defined narratives as assumptions about the past that cannot be true or false, only useful and fruitful, or vice versa (Ankersmit, 1994). Rather, sociologists consider the narratives of ordinary people as not singularly reflecting, singularly reproducing, or singularly constituting social reality, but as doing all the above at the same time. Thus, every narrative is a fictionalized story enriched with the narrator's interests and priorities. However, a narrative does possess some "similarity" with the real world: we cannot apply the criterion of truth/falsity to narrative interpretations for they have subjective justification, and, by this very fact, are at least emotionally true. Besides, every narrator believes that his narrative is true simply because his self-descriptions seem authentic to him at the moment of narration (see, e.g., Suchan, 2004: 304). This is why narrative analysis considers language not as an instrument of reflection on the external world, but as a means and condition for constructing meanings. In other words, narratives tend to be the truths of the experience ("temporal constructs"), and narrative analy- 
sis studies real people with their real life experiences in the real world by interpreting meanings that social actors prescribe to the experienced events.

The above mentioned second line of the debates about the 2015 Nobel Prize in Literature, considering the "status" of Alexievich's works as fiction or non-fiction is extra/ outer-disciplinary for the question that underlines such debates is central for contemporary social life in general: who has the right (duty, or responsibility) to write about war, and to suggest linguistic, thematic, discursive and implicit ideological formats to speak and to think about the most tragic events of personal and social history? I like the notion of "wise literature" used by Alexander Markov to justify the decision of the Swedish Academy (Markov, 2015). He believes that the catastrophes Svetlana Alexievich writes about are supra-personal tragedies, which raises the question of who has the right or responsibility to discursively record them for the present and future generations. The representatives of narrative analysis would say that this right belongs to the witnesses and direct participants of war events being a part of their biographical experience. In addition, these narratives may be restorative, for instance, as they largely contributed in successfully getting rid of many stereotypes of the German public during World War II (Kyari, 1996: 250). Such a micro-optics allows us to see the whole historical and sociocultural context in a single personal story narrated in given space-time coordinates. This explains why and how this type of narrative became socially symptomatic or typical, regardless of recognizing the fact that there is always a "gap" between the reality of life and the reality of the story about it (Bourdieu, 2004).

In its turn, the macro-optics focuses on issues other than personal experience during wars, such as the relationships between war and peace, warfare and armament, on war as a part of cultural rituals, and discourses of collective social actors. One can say that there are adequate and institutionalized sociological methodological principles and technical decisions to study war-connected phenomena in contemporary society and in different periods of the past at this level of analysis. Certainly, there is nothing to argue about; on the contrary, there are generally known conceptual models to think about, to study, and to write about war. However, the macro-optical perspective inevitably misses the substantial meanings and emotions that turn wars into the most epiphanic moments of our lives and, thus, into biographical narratives, which explains the popularity of (non-) fiction works as a means a society at war tries to understand itself with, even if it is with difficulty and horror. In brief, even within the qualitative approach, no interviewer is able (or strives) to become "an ear" (Saprykin, 2015) recording every personal story as it is, that is, not as an interesting and socially significant typical integration of personal and social experience, but into a narrative form reflecting the dominant social ideological scenario. Unlike fiction and non-fiction literature, all scientific studies fail to convincingly show, till the shuddering heart, that war is a perfect mechanism of bringing the price of human life and dignity to zero. Here, let us compare scientific and non-scientific ways of demonstrating this unique feature of every war.

Sociological books are never as popular and cited as recently-numerous fiction and non-fiction literature, regardless of the amazingly-old discursive attempts to describe and 
explain war, seemingly to be the most integral part of human history. Perhaps scientific texts (by definition, by nature, or by the ambitions of the authors) seem too abstract for an average reader, because they provide information that is (a) not interesting ${ }^{9}$, or (b) too often repeated in the mass media and, thus, looks too obvious, too clear, and too simple. For example, we can not only name a wide range of negative consequences of every war, such as the abnormal conditions of social organisms, the destruction of social system values, norms, and institutions, millions of victims and destroyed economies (this is often the price for an unchanging situation), a negative impact on the socialization process, a sharp population decline, etc., but also war's positive consequences, such as the creation of external group boundaries, promotion of group identity, the strengthening of internal cohesion, the centralization of the group for cooperation, etc. Scientific books do not say much about how a person feels about war in all its manifold manifestations, how he manages to survive, how dehumanization takes place in each particular case (sociology is not interested in personal matters, only in socially typical and symptomatical ones). As N. N. Golovin aptly noted (1997: 467): "Sociologists directed all their efforts on the study of the role played by war in the life of humanity ... primarily its causes and consequences ... and do not study only one thing - the war itself."

Thereafter, to overcome such a limitation of the sociological study of war, we turn to the personal narratives of those who happened to witness war from "within." And once again, we must admit, that in collecting and presenting such biographical stories, sociology loses out to fiction and non-fiction literature simply because the latter is not bound by the requirement to explicate the results of the analysis of a single narrative on the broad socio-cultural context, not in the sense of statistical representativeness, but as a step in the construction of sociological definitions and interpretations. Non-sociological texts must only be interesting, exciting, and look realistic; they do not have to follow the many steps that guarantee, albeit partly, the correct sociological "translation" of war witnesses' narratives into scientific text, such as evaluating the level of a story's truthfulness, identifying the specific meaning of the text, structuring the content of the narrative in accordance with sociologist's criteria, the social "localization" of the narrator, etc. All these steps and related problems are irrelevant for fiction and non-fiction literature which exaggerates the meaning of some features of personal life stories that narrative analysis takes into account, such as every narrator considering his story as an authentic self-description at the time of narration (see, e.g., Suoninen, 2001: 304). In addition, we acquire knowledge of the past in the narrative form, i.e., when one reads a narrative, he reads a narrative, and there is nothing to add (see, e.g., Ankersmit, 1983). This is too shaky a foundation for the sociological study of war, but a perfect one to attract a reader's attention and to create an illusory impression of knowing the truth about a man at war by looking at it through his eyes.

9. For instance, my own content-analysis of the discourses on the Russian-Chechen military confrontation in the media aimed to identify whether or not the concept of "war" was used by different "evaluators," and which terminology prevailed in different periods, i.e., during the first and the second Chechen campaigns (Trotsuk, 2005). 


\section{Fiction or Non-fiction-What to Prefer?}

In short, the reasons above are why people prefer to find out about wars either from the media/news (if interested in knowing what is going on in the world), or from fiction and non-fiction books. The former are probably preferable to those who want to capture the emotions or the feelings of "a man at war" without being touched to the very depths of their heart, because fiction books tell us about fictional characters. The latter are much more shocking, for we know that their heroes are as real as we are, and what we learn from such books could have happened to us if we had been unlucky enough to witness war as described through real-people's real stories (slightly fictionalized, as are all biographies "for sale"). One of the most recent illustrative examples of fictional war-stories (it is important to refer to this book because it was translated into Russian just last year, a year before Arkady Babchenko's book was published) is the 9oo-page book by Jonathan Littell, The Kindly Ones (Les Bienveillantes) (Littell, 2014). The story is narrated by the fictional Maximilien Aue, a former SS officer of French and German ancestry, who describes his personal experience of being part of several major events of World War II. In one of his interviews, it is noteworthy that Littell emphasized a highly significant aim of his work in saying that he "was seeking the novelistic truth, not the plausibility" and stressed that this type of truth was different from historic or sociological ones. As his literary agent said, Littell wrote "intimate memoirs of an ex-Nazi mass murderer" (Landler, 2006). This intimacy that involves, shocks, and excites is probably what attracts readers from all over the world. However, these are kinds of artificial feelings, because we know that this is a story of a fictional character, although in real historical circumstances ${ }^{10}$. While reading, we follow imaginary characters and events that merge into a historical representation of the Nazi regime, German culture, and war-torn Europe.

To write the book, Littell conducted 18 months of research traveling to Germany, the Ukraine, Russia, and Poland, and read dozens of books about World War II and the postwar trials of the Nazis to understand an executioner' thinking and the origins of state murder, retrospectively imagining what he would have done and how he would have behaved if he had been born into Nazi Germany. Littell also had the experience of working for the international humanitarian organization Action Against Hunger in Bosnia, Herzegovina, Chechnya, The Democratic Republic of Congo, Sierra Leone, and Afghanistan, and saw the consequences of the actions of war and mass sufferings. Nevertheless, his book caused fierce debates in European countries. Most critics recognized the author's talent as a novelist who created a masterpiece (and a bestseller, at least in France), but his attempts "to describe the Hell" made some critics call the book the first terrifying "work of fiction to come out of the Holocaust that places us in its very heart" (Korda, 2009), and named its author as "a pornographer of violence" (Mönninger, 2006). It must be noted, however, that German critics panned the book (see, e.g., Uni, 2008).

10. In some interviews, Littell mentioned that he wrote the book after he discovered a photo of Zoya Kosmodemyanskaya, a female Soviet partisan hanged by the Nazis in 1941 and watching the movie "Shoah" by Claude Lanzmann, invoking his interest in the bureaucratic aspects of genocide. 
Regardless of the controversial subject matter of Littell's narrative, hardly anyone doubts that his book is an outstanding historically, intellectually, and emotionally powerful novel, "a monumental narrative" and "the first novel to engage the Nazi genocide in a nonallegorical mode" (Sanyal, 2015: 192). The debates mostly considered the key idea of this fictional wartime memoir easily identified by its (probably, scientifically-oriented) conscientious readers (see, e.g., Ascherson, 2009) as the enduring mystery of how a large number of human beings could have consented to carry out the appalling acts of cruelty and savagery or been aware of them without experiencing an overwhelming revulsion. Littell's narrator is a self-confessed killer, represented as a man who carried out numerous murders ad hominem as a part of the "machinery" of genocide, both observing and participating in mass murders and the management of the network of concentration and death camps (Hutton, 2010: 9). With the statement that nearly everyone in a given set of circumstances does what he is told to do (a bureaucrat simply follows orders), Littell reasserts, through the eyes of a former Nazi perpetrator, Arendt's notion of the banality of evil (the uncomfortable moral scenario that leads ordinary individuals to commit heinous atrocities for the most trivial and arbitrary reasons [Arendt, 1965]), thus providing a greater psychological insight into the banality of evil than the documentary historians (Catani, 2015: 662).

Considering Littell's book after Svetlana Alexievich won the Nobel Prize for non-fiction stories of historical events she did not participate in, it would be strange to think that authors who took part in war events describe it in the non-fiction format, while those who did not do so in fictionalized stories. Nevertheless, if one had actually witnessed some tragic events from the "inside," one have the possibility to decide what the degree of fiction would be in one's (in any case) biographical narrative. In most such cases, authors seek a compromise between fiction and non-fiction to achieve a credibility of the realities presented in the text with the means of artistic imagery. However, Russian literature tends to produce emotional rather than rational and non-emotional narratives (such as Littell's book) about wartime, while at the same time preferring to look at war through the eyes of good men (heroes and victims) and not the executioners' (as in Littell's book). One good example is the novel, Pathologies (Prilepin, 2005), about the Chechen war by the Russian writer Zakhar Prilepin, landing its author on the 2005 Russian National Bestseller Award ${ }^{11}$ short list, and translated into French in 2007. In the first pages, Prilepin characterizes his book not only as an adventure thriller, ${ }^{12}$ as an extremely frank story about real military work, the essence of which is not only the mutual destruction of fighting people, but also as a story of a violent, crazy love (probably, Prilepin's descriptions of the emotional experience of a loving man are among the strongest, most convincing, and touching in contemporary Russian prose). In one of his interviews, Prilepin mentioned

11. It should probably be noted that Svetlana Alexievich considers Zakhar Prilepin, also a well-known Russian writer abroad, her opponent as a representative of contemporary Russian intellectual elites supporting the political regime and militarized public consciousness (see, e.g., Gordeeva, 2015).

12. Although there are some features of such in the story about the fate of one fearless soldier at war that make us believe from the very beginning that even in the most serious moments of the Chechen war, the hero will survive, and nothing bad will happen. 
that he planned to write a novel about love, but eventually, after three or four years of work, it turned into a novel about Chechnya, according to the famous Russian saying that whatever Russians do, it always turns out to be a Kalashnikov.

Zakhar Prilepin fought in Chechnya as an officer of the Russian paramilitary police, but this did not prevent him from criticizing his own brutal unit, the OMON. Prilepin is a very controversial figure for, on the one hand, every one of his books is a bestseller, especially among young urban readers, and he won a major literary award for being the best new writer of the last decade. On the other hand, he is a very active person with unstable political preferences which often makes him an object of severe criticism from both supporters and opponents of the current political regime. Nevertheless, Prilepin's political position does not interest us now, so let us turn to his most famous book of the Chechen war, Pathologies. For the most part, the text is dark because of the commonness of killings and deaths, but at the same time, in some sense, the author romanticizes war as an extreme state of human life that suddenly selects people who demonstrate amazing reserves of strength, love, and patience unprecedented in peaceful life.

Prilepin's two tours of duty in Chechnya became the basis of Pathologies, but he denies that his book is true, and insists on writing a fictional novel, not an autobiography. At the same time, he accepts that most things he describes really did happen to him (for example, his driver was shot in an ambush just yards from him), and intoxicated him with the rituals and bonds of maleness, and, by extension, by the perception of war as the ultimate test of manhood. Some critics praised the book for its neutrality (both patriots and opponents of the Russian army and politics can refer to it for support), but this is not neutrality-it is a very frank and ascertaining life-narrative without heroes, situations, and events hypertrophy (perhaps slightly). Military routine, poverty, disease, death, and sex are described with the same physiological accuracy, almost unemotionally, which softens the story about everyday life during the Chechen war. However, this seeming lack of emotion emphasizes how illusory the distinction between normality and pathology, or between life and death, is (that is why the most calming activity for the author at war is cleaning his machine), thus, convincingly showing that we live in a beautiful, and at the same time, fragile world. As Prilepin puts it in his book: "God holds the world as an exhausted thirsty child holds a cup of milk: with tenderness and trepidation ... But he can easily drop it."

\section{Why We Are to Read about the Chechen Wars Again?}

To be honest, I thought that the theme of the Chechen wars was exhausted by the end of 20oos, partly due to the state official rhetoric considering the current situation in the Chechen Republic, partly due to the more urgent war conflicts Russia has recently been taking part in, and partly due to the already published works such as Prilepin's Pathologies. That is why I thought that War by Arkady Babchenko was a collection of non-fiction stories about the author's journalistic trips to Ukraine, mainly to Donbas. Babchenko is famous for mastering the journalist profession after his military service in the Russian 
army, in which he took part in both Chechen campaigns. Later, he visited many hot spots, including those in the Ukraine, and, unlike Zakhar Prilepin today, openly declares his disagreement with the official position of the Russian authorities on his Facebook page with thousands of followers. On this page and in interviews, Babchenko has repeatedly expressed his opinion about the situation in Donbas, often finding parallels between the Donbas conflict and the first Chechen war. Firstly, Russia entered the conflict in 1994 in exactly the same condition as Ukraine did in the Donbas war from economic, political, and military points of view. Secondly, whatever the official authorities or the media say, people on both sides of the Russian-Ukrainian borders know what is really going on (as it was in Chechnya many years ago). Thirdly, in the recent war conflict, no one has ever counted casualties; we still do not know how many soldiers were killed in Chechnya, and no one is going to count the Russian citizens who died in Donbas. Another significant aspect common to all wars in modern human history which interests Babchenko the most is post-traumatic stress disorder, or PTSD.

The book War consists of 18 short stories. The first three are the heaviest, impressive, and memorable, for they form the thematic and evaluative framework for the rest of the book, which mostly provides a more-detailed description of the people, places, events, and situations mentioned in the first three short stories after the introduction. The latter provides a short biographical explanation of how Babchenko arrived to the first Chechen war, and what hardships he passed through as a soldier in the Russian army, hardships sometimes too horrific to write about in any other manner than humorous: "Our invincible army, presented by the hefty drunken sergeant-paratrooper, greeted me with promising words: 'Well, faintings, here you are in the army ... Who wants to get in the snout?' I did not like the beginning of my military service" (Babchenko, 2015: 6).

The first short story, Airstrip, provides a brief description of the biographies of the boys with whom Babchenko was waiting with to be sent to the war zone in the heart of Chechnya. He writes about how they got there, who and what they were afraid of, why they became so important for Babchenko, and how he will remember each of them for the rest of his life (for example, Andryuha will always stay in the author's memories as a small, thin guy, like a dried cockroach). In this short story, all the boys are still alive and happy, basking in the sun and living in the moment. Babchenko describes his first impressions about what was going on in Chechnya during the first war as a terrible mess, with constant movement, crowds of people consisting of journalists willing to pay any amount of money to board the next helicopter to Chechnya, and soldiers willing to be as far away from there as possible: the former were left at the airstrip, while the latter were taken to Chechnya- "that is how weird life is" (Babchenko, 2015: 18). Here the author saw the first wounded victims in his life, with mad eyes and blackened faces, who screamed, cried, and stunned themselves with tons of vodka. For the first time, the author captures the staggering incompatibility of wartime and the wonderfully peaceful life around it: "War must go on where everything is bad, and not where life is so good. The war must go on beyond the Arctic Circle, where life is grim and gloomy and people do not see sun for months. We do not believe that we were brought to this place, which looks like 
a beginning of heaven with its smell of apricots, to be put into silver bags for corpses" (Babchenko, 2015: 25).

The second short story, Mozdok-7, describes routine robberies, the beatings and abuse of soldiers in the barracks full of arrant lawlessness and chaos in the first Chechen campaign, for the officers returning from the war zone "were giving orders only with punches. They did not care about anything-soldiers' lives, the Chechens' lives, their own lives ... They wanted only one thing-an endless war with people to kill . .." (Babchenko, 2015: 40). Such a routine stultified the soldiers, and they were terrified that they were only beaten and did not learn how to fight. They wondered very rarely who started that war and blamed "the bureaucratic gang that existed only to have them beaten and clobbered in the barracks, and then led to the airstrip, put in the copters and killed somewhere over the ridge" (Babchenko, 2015: 67). Most of the soldiers did not understand whom they were fighting against: "If the Chechens are enemies of Russia, then we have to kill them all unceremoniously ... if they are Russian citizens, then how can we fight against them?" (Babchenko, 2015: 68). Babchenko completes this part of the book with the statement that "a man at war is changing very quickly, and if on the first day you are frightened by a dead, then a week later you eat your canned meat leaning on the torn off head so as to sit more comfortable. These bodies, which lie next to us, are just dead people, that's all" (Ibid.: 85).

The third short story, Summer of ninety-six, is devoted to the roads of war, on which each barrier and checkpoint, like an invisible border, cuts soldiers off from their previous life with no turning back. Babchenko describes everyday life in the tents and barracks where people have to fight heat, thirst, hunger, diseases, and constant beatings, sometimes when leaving for the war zone to be struck by the fact that life goes on, and that life is wonderful in its strangeness against the background of the black, ugly war. Although the author's narrative is rather unemotional and ascertaining for the most part, it is interspersed with brief descriptions of the horrors of war, like the terrible fates and sufferings of soldiers' mothers looking for their children, executions of prisoners, deaths of the wounded, accidents, violent killings out of revenge, and more, all permeated by the single and all-consuming desire of the soldiers-boys to survive.

The rest of the book describes different aspects of life during war in more detail, addressing the topics of the first three stories already drawn in broad strokes. Argun is a cinematic depiction of the soldiers' feelings of happiness in rare minutes of calmness between the fighting and mockery, and of the absolute loneliness, abandonment, deception, and fear of a man at war that makes him an insane aggressor. Soldier's Dream shows that the night dreams in war are as terrifying as the reality itself. On the contrary, New Year shows that dreams reminding him of a happy peaceful life can save a man from going insane. Storm very convincingly describes the banality of war actions one at first expects to see in heroic colors, but they turn out to be as simple and trivial as everything a man does in his everyday life. Peace shows that hatred begets only hatred, resulting in soldiers hating not only the Chechens they fight against, but also their officers, and that this feeling is overwhelming, mutual, and largely deserved. Special Cargo mesmerizes with the realistic 
description of the routine dealing of the dead and death, and draws a kind of borderline between two parts of the book. In this section, we are dealing with the fictional character of Artyom, or somebody not precisely identified, although the character possesses the same biographical features, and describes the same situations and feelings of a man in a war who happened to fight and almost freeze to death in Alkhan-Yurt, who understands Wartime Fraud and the strangeness of being alive while visiting peaceful places he used to fight in a few years ago.

The book War is titled in both Russian and Chechen, so the expectation is that the author will try to show the international dimension of the Chechen war by describing both sides of it. However, the book turns out to be too "Russian." Of course, there are schematic and impersonal Chechens, or rather "the Czechs," not as the main villain, but rather as some background scenery causes of death, firing at the positions of the Russian troops, cutting off the heads of prisoners, stabbing, strangling, and crucifying their captives. Although the Russian soldiers do the same during their sweeps, the difference is that the author describes his brother-soldiers in personal terms as they live and try to survive the awful life in these terrible places together, while the Chechens are like some ephemeral messengers of death that acquire a human face for a moment if they are civilians to trade with, or policemen supporting the Russian troops, or good people saving soldiers from humiliation and war. The transiency of this subjectivity of the Chechens is explained in the book. Civilians of any age and gender can kill Russian soldiers with a knife to the throat or a bullet in the head, while, the next moment, they are selling the Russians vegetables in the market. Although the situation in Chechnya changed radically after the first campaign, even in the second Chechen campaign there were no positive or negative Chechens for Babchenko-only some blurred, as if distant, figures, but still potentially dangerous and deadly ones.

The main and the only characters in the book are Russian soldiers (regardless of their ethnic origin which varies from Jewish to the Dagestani and the black boy Min'ka, whose father was from Guinea), who are neither heroes nor anti-heroes because war destroys the demarcation line between these two options. Just after the publication of the book, some critics wrote that the worst and the most frightening thing in it are not the killings, but the bullying, the cruel commanders, and the state and army authorities' absolute indifference of the soldiers who regularly suffer hunger and dysentery, turn gray at the age 18 , and most importantly, are constantly beaten and humiliated to break them down, for extortion, just for fun, or out of revenge if they try to fight back, whether behind enemy lines or on the frontlines. These critics sometime mention that there are so many descriptions of beatings and humiliations that a reader unwittingly waits and hopes for the main character to take up the machine gun and shoot all his abusers. It is clear that he does not because the novel is largely autobiographical, and we know that Babchenko is not in prison for murder. However, I strongly disagree with the critics who allegedly do not understand why the hero preferred horror without end to a terrible personal end: while being opposed to the system which sent him (as many other soldiers) to death and humiliation, he chose to buy into it and to become a part of the machine that repressed him. 
Those who are beaten, start beating; those who suffer from hunger caused by the thefts of procurers, begin to steal, too; soldiers sell weapons to the enemy to get money, because everybody steals and sells weapons, the only difference being in the scale of the crime and bullying. All these monstrous traditions are accepted as the norm of army life, and are aggravated by the proximity of death in wartime. As the author humorously describes his feelings in the first two weeks of military service before being sent to the first Chechen war, he "thought he would die, but later understood that on the army's standards it was paradise" (Babchenko, 2015: 6).

Babchenko repeatedly offers explanations for the extreme cruelty of a man at war. Any cruelty towards the enemy is justified by the belief that the soldier fights against evil and injustice, but this is probably the most terrible tragedy of every war: under the slogan of fighting against evil and injustice, armies multiply them in every possible way. In its turn, the cruelty to one's own soldiers is a result of a strange, inexplicable, irrational (according to Zakhar Prilepin, pathological) mixture of the awareness of the inevitability of death and the will to live, is mainly responsible for PTSD, and explains the author's surprising fatalism of his decision to voluntarily return to Chechnya during the second campaign. The cruelty and indifference to one's brothers-soldiers' sufferings are the result of getting used to death's proximity, inevitability, and unpredictability, since, in war, all combatants "live this very minute" (Ibid.: 15); there are "peace and corpses at the same time" (Ibid.: 22) $)^{13}$; "everybody hates everyone, hatred and insanity hang in the air like a heavy stinky cloud to impregnate new-comers with fear, like a barbecue with lemon juice, before sending new cannon fodder in a war grinder-to help them to die" (Ibid.: 59); "everybody believes that they all will be killed in this war" (Ibid.: 73); with indifference and "cynicism soldiers treat themselves not to go mad completely" (Ibid.: 81); "when the whole cannon fodder will die-in silence and unfairly" (Ibid.: 84); and "nothing changes after somebody dies ... for death at war is as natural as hunger, thirst and beatings a thousand or ten thousand years ago" (Ibid.: 109).

Thus, we can turn to the words with which Jonathan Littell starts The Kindly Ones: "My human brothers, let me tell you how it happened" (originally, in French, it read as "friends," but the author agreed that this word did not work as well). Littell wanted to show that understanding the Germans of sixty years ago may make one feel that one is not that far from it, as one is used to think, and may make one enforce one's social mechanisms to prevent one's societies from getting into similar wars. Many years after the Chechen campaigns, Arkady Babchenko published a book devoted to probably the same reasons, in order to show that nothing has changed (therefore, the comparison of the dead town

13. These are really the most terrifying pieces of texts-describing how wonderful nature and the world are, absolutely ignorant to human sufferings and the circle of life and death shown throughout the book by the incessant arrivals and departures of military helicopters that load both dead and live people, like sacks of potatoes, surrounded not by white and black, but by wonderful, colorful life. 
of Grozny in 1996 with Stalingrad is not accidental), and that all wars are bad, cruel and senseless, regardless of how one prefers to name them. As Babchenko mockingly writes about the first Chechen war, the Russian troops were officially fighting not against the Chechens, but against illegal armed gangs, not because they wanted independence, but because the Constitution says that no region can secede from Russia just like that: he writes '"restoration of the constitutional order,' 'anti-terrorist operation'-just meaningless words, invented to justify killing of thousands of people" (Ibid.: 69).

Unlike Zakhar Prilepin who slightly romanticizes war as a realm of men's brutality, Babchenko's narrative is full of tough men's humor and social satire to emphasize the ordinariness of evil in war.

\begin{abstract}
Here a man is not a man, but some other creature ... It is not possible to tell about the war to those who did not fight at it-not because they are stupid or blunt, but because they simply lack the sense to feel it . . Nobody returns from war. Never. Mothers get back only a pitiful semblance of their sons-aggressive angry beasts, embittered on the whole world and not believing in anything except death ... Yesterday soldiers still belong to war, from which only their bodies came back. Their souls stayed there ... And here you are-a yesterday ensign, soldier, or captain, a hundred times contused, all riddled, darned and pieced together, half-mad and stupefied-writing and writing, and whining from weakness and despair, and tears running down your face... And the bloody lines go one by one, and you drink liters of vodka, and death and madness sit with you in the arms, push you in the side and help you to write. (Ibid.: 124, 346, 348)
\end{abstract}

I am sure the quotes above do not remind any reader, whether an average person buying fiction or non-fiction books, or a representative of the social sciences, of the traditional scientific representations of war. The latter hopelessly, albeit convincingly and nicely, seeks to explain the reasons and consequences of war rationally and "from a distance," rather than to represent them through the biographical narratives of those who have actually experienced such causes and effects. For instance, most social scientists admire the famous theory of J. Huizinga who introduced an agonistic interpretation of war as a function of culture based on the notion of glory rather than "any rational and intellectualist theory of economic forces and political dynamisms" (Huizinga, 1949: 59, 90). Certainly, there are many famous names in the history of military science, but researchers of war never forget to refer to the works of C. von Clausewitz, who defined war as "an act of violence intended to compel our opponent to fulfill will" (Clausewitz, 1874), and named three main objects of warfare: "to conquer and destroy the armed power of the enemy; to take possession of his material and other sources of strength, and to gain public opinion" (Clausewitz, 1942). The books of these two prominent war theorists are constantly reprinted, but cannot compete in popularity with fiction and non-fiction books on war. The reason is not that these two conceptions are too old or outdated, although Huizinga himself recognized that war had lost its play-quality and connections with the cult and festival, i.e., its "status" of an element of culture, while the theory of Clausewitz was 
criticized by M. van Creveld in his famous Transformation of War. I believe the reason is different: such books are too rational-explanatory, while people want to see the "human dimension of war," to have a look at warfare through the eyes of a "simple combatant" ("a man with a gun"), that is, to understand what the war really was for the one who happened to be in the thick of it, instead of learning why and who "from above" unleashed it.

Besides, there is a faint hope that if we do not trust in the ordinariness of evil in war just like that, perhaps the words of a witness and a direct participant can convince us. Perhaps the power of conviction and the level of trust is the only significant difference between fiction and non-fiction in war prose. However, looking at the world around us, we must admit that both (not to mention all the scientific calls for peace) seem to fail to convince us otherwise.

\section{References}

Ankersmit F. R. (1983) Narrative Logic: A Semantic Analysis of the Historian's Language, Den Haag: Nijhoff.

Ankersmit F. R. (1994) History and Tropology: The Rise and Fall of Metaphor, Berkeley: University of California Press.

Arendt H. (1965) Eichmann in Jerusalem: A Report on the Banality of Evil, New York: Penguin.

Ascherson N. (2009) Such Amateurishness ... London Review of Books, vol. 31, no 8, pp. 11-13.

Babchenko A. (2015) Voyna [War], Moscow: Alpina Non-fiction. (In Russian)

Bourdieu P. (2004) The Biographical Illusion (transl. Y. Winkin, W. Leeds-Hurwitz). Identity: A Reader (eds. P. Du Gay, J. Evans, P. Redman), London: SAGE, pp. 297-303.

Catani D. (2015) Hannah Arendt Reconsidered: Collaboration and the Banality of Evil in Jonathan Littell's “The Kindly Ones.” Sociology Study, vol. 4, no 8, pp. 661-672.

Clausewitz C. von (1874) On War (transl. J. J. Graham). Available at: http://www.gutenberg.org/files/1946/1946-h/1946-h.htm (accessed 20 November 2015).

Clausewitz C. von (1942) Principles of War (transl. H. W. Gatzke), Harrisburg: The Military Service Publishing Company.

Creveld M. L. van (1991) The Transformation of War, New York: Free Press.

Franzosi R. (1998) Narrative Analysis-or Why (and How) Sociologists Should Be Interested in Narrative. Annual Review of Sociology, vol. 24, pp. 517-554.

Golovin N. (1997) O sociologicheskom izuchenii voyny [On the Sociological Study of War]. Sociologija v Rossii XIX - nachala XX vekov [Sociology in Russia of the 19th Early 2oth Centuries], Moscow: Mezhdunarodniy universitet biznesa i upravleniya. (In Russian)

Gordeeva K. (2015) “Ty ryadom s kotletkoy po znachimosti i ne mechtay vstat"': Interv'ju pisatel'nitsy Svetlany Aleksievich ["Do Not Even Dream to Stand Close to the Cutlet by Importance": Interview with Writer Svetlana Alexievich]. Available at: https://me- 
duza.io/feature/2015/09/30/ty-ryadom-s-kotletkoy-po-znachimosti-i-ne-mechtayvstat (accessed 20 November 2015). (In Russian)

Huizinga J. (1949) Homo Ludens: A Study of the Play-Element in Culture, London: Routledge \& Kegan Paul.

Korda M. (2009) A Brilliant Holocaust Novel. Available at: http://www.thedailybeast. com/articles/2009/02/25/a-brilliant-holocaust-novel.html (accessed 29 November 2015).

Kyari B. (1996) Ustnye svidetel'stva Vtoroj mirovoj voyny [Oral Evidences of World War II]. Sociological Journal, no 3-4, pp. 246-257. (In Russian)

Hutton M.-A. (2010) Jonathan Littell's Les Bienveillantes: Ethics, Aesthetics and the Subject of Judgment. Modern \& Contemporary France, vol. 18, no 1, pp. 1-15.

Landler M. (2006) Writer's Unlikely Hero: A Deviant Nazi. Available at: http://www.nytimes.com/2006/10/o9/books/ogfran.html?_r=o (accessed 29 November 2015).

Littell J. (2014) Blagovolitel'nitsy [The Kindly Ones], Moscow: Ad Marginem. (In Russian)

Maines D. R. (1993) Narrative's Moment and Sociology's Phenomena: Toward a Narrative Sociology. Sociological Quarterly, vol. 34, no 1, pp. 17-38.

Markov A. (2015) Igra i mudrost': Nobelevskaja premija Svetlany Aleksievich [Game and Wisdom: The Noble Prize for Svetlana Alexievich]. Available at: http://gefter.ru/archive/16177?_utl_t=fb (accessed 20 November 2015). (In Russian)

Mönninger M. (2006) The Banalisation of Evil. Available at: http://www.signandsight. com/features/976.html (accessed 29 November 2015).

Murakami H. (2000) Underground (transl. A. Birnbaum, P. Gabriel), New York: Vintage. Prilepin Z. (2005) Patologii [Pathologies], Moscow: Andreevskiy flag. (In Russian)

Sanyal D. (2015) Reading Nazi Memory in Jonathan Littell's The Kindly Ones. Memory and Complicity: Migrations of Holocaust Remembrance, New York: Fordham University Press, pp. 182-212.

Saprykin Y. (2015) "My pereputali dobro so zlom": interv'ju so Svetlanoy Aleksievich ["We Have Mixed Good and Evil": Interview with Svetlana Alexievich]. Available at: http://vozduh.afisha.ru/books/my-pereputali-dobro-so-zlom-intervyu-so-svetlanoyaleksievich (accessed 20 November 2015). (In Russian)

Suchan J. (2004) Writing, Authenticity, and Knowledge Creation: Why I Write and You Should Too. Journal of Business Communication, vol. 41, no 3, pp. 302-315.

Suoninen M. (2001) Mikrohistoria vastauksena historiallisen sosiologian dilemmaan. Sosiologia, vol. 38, no 1, pp. 14-26.

Trotsuk I. (2005) Sociologija voennyh konfliktov: sobytija 1994-2001 gg. na territorii Chechni [Sociology of War Conflicts: Events of 1994-2001 in Chechnya]. Obshhestvo i gosudarstvo: Materialy mezhdunarodnogo seminara 4-5 noyabrya $2004 \mathrm{~g}$. [Society and State: Proceedings of the International Seminar (November 4-5, 2004)], Moscow: MSSES, pp. 111-127. (In Russian)

Uni A. (2008) The Executioner's Song. Available at: http://www.haaretz.com/the-executioner-s-song-1.246787 (accessed 29 November 2015). 


\section{Странности рецензирования, или К чему приводят попытки зафиксировать частно-человеческое «измерение» войны}

\section{Ирина Троиук}

Доктор социологических наук, доцент кафедры социологии факультета гуманитарных и социальных наук Российского университета дружбы народов

Адрес: ул. Миклухо-Маклая, д. 10/2, Москва, Российская Федерация 117198

E-mail: irina.trotsuk@yandex.ru

Первоначально данная статья задумывалась как рецензия на вышедшую в 2015 году книгу Аркадия Бабченко «Война», но текст решил зажить собственной жизнью и превратился в обзор/эссе, породив у автора подозрения в сомнительности его исходного замысла. С одной стороны, не вполне понятны причины возвращения Бабченко к теме двух чеченских кампаний в 2015 году, учитывая его огромный опыт работы в качестве военного корреспондента в других горячих точках. С другой стороны, «Война» - один из ярчайших примеров современной военной прозы и поднимает ряд важнейших социологических вопросов, что снимает сомнения в необходимости рецензирования этой по определению несоциологической работы для однозначно социологического издания. Подобные книги неизбежно запускают очередной виток социологически «нагруженных» дискуссий: вопервых, о статусе нарративов - обыденные повествования и логика их конструирования обрели сегодня столь же легитимный статус, как и научные тексты, поэтому социологи обращаются к повседневным «показаниям» в рамках «микросоциологического» анализа войны. Во-вторых, о том, кто обладает правом писать о войне, задавая, тем самым, лингвистические, предметные, дискурсивные и скрытые идеологические форматы ее проговаривания и осмысления. Безусловно, в социологии давно сложились адекватные и институционализированные методологические модели описания и объяснения войн, однако макрооптика неизбежно упускает из виду те значения и эмоции, что превращают войны в эпифанные моменты, отраженные в биографических нарративах. Для преодоления этого ограничения макрооптики мы обращаемся к повествованиям тех, кто видел «изнанку» войны и смог описать ее в формате художественного произведения (например, Джонатан Литтелл в романе «Благоволительницы») или автобиографической публицистики (например, Захар Прилепин в романе «Патологии»). Второй формат более свойственен современной российской литературе и рассмотрен в статье на примере книги Аркадия Бабченко «Война». Впрочем, оба формата позволяют увидеть «человеческое измерение войны», и, видимо, единственное различие между ними - сила убеждения и уровень читательского доверия. Ключевые слова: война, Аркадий Бабченко, нарративный анализ, художественная литература и публицистика, Джонатан Литтелл, Захар Прилепин, «микро-» и «макро-» подходы к социологическому изучению войны 